\title{
Geographic Information System for Mapping and Complaint of Damaged Roads
}

\author{
I Made Widiana Putra Winarta ${ }^{\mathrm{a} 1}$, I Nyoman Piarsa ${ }^{\mathrm{a} 2}$, Ni Made Ika Marini Mandenni ${ }^{\mathrm{a} 3}$ \\ anformation Technology Dapartment, Faculty of Engineering, \\ Udayana University Bukit Jimbaran, Bali, Indonesia, phone +62361703315 \\ e-mail: ${ }^{1}$ widianaputraa@gmail.com, ${ }^{2}$ manpits@unud.ac.id, ${ }^{3}$ made ikamarini@unud.ac.id
}

\begin{abstract}
Abstrak
Indonesia merupakan sebuah negara kepulauan yang memiliki luas daratan sebesar $1.919 .440 \mathrm{~km}^{2}$ dan memiliki jumlah panjang jalan sebesar $542.000 \mathrm{~km}$. Kondisi geografis Indonesia menyebabkan pengelola jalan sulit untuk melakukan pemeliharaan jalan sehingga dapat menyebabkan kecelakaan lalu lintas. Sistem Informasi Geografis Pemetaan dan Pengaduan Jalan Rusak merupakan sebuah sistem digital berbentuk layanan yang memungkinkan pengguna untuk melakukan pengaduan terhadap jalan rusak yang ditemui sehingga dapat langsung tersampaikan kepada pihak pengelola jalan. Sistem ini menggunakan Google Maps API untuk melakukan digitasi jalan dan pengaduan jalan. Hasil dari penelitian ini yaitu berupa aplikasi android untuk pengguna dan aplikasi website untuk pengelola jalan. Aplikasi android digunakan oleh pengguna untuk melakukan pengaduan jalan berdasarkan titik yang dimasukan melalui Google Maps. Aplikasi website digunakan oleh pengelola jalan untuk melakukan digitasi jalan dengan menggunakan fitur polyline pada Google Maps sehingga penyampaian informasi dan penanganan pengaduan menjadi lebih cepat.
\end{abstract}

Kata kunci: Digitasi Jalan, Google Maps, Jalan Rusak, Pengaduan, Sistem Informasi, Geografis.

\begin{abstract}
Indonesia is a massive archipelago of $1.919 .400 \mathrm{~km}^{2}$, containing roads that span at $542.000 \mathrm{~km}$ across various terrain conditions. This diverse geographic environment is a challenge to road constructions and repairs across the country, which has lead to disruption in public service and traffic accidents each year. We propose the Geographic Information System for Mapping and Complaint of Damaged Roads, a solution which can provide users a digital interface to report damaged roads to the transportation department in their area. This research uses Google Maps API to digitize and make a complaint about damaged roads. The result of this research is an android application for the users and a website application for the road managers. The android application is used by the users to make complaints of damaged roads. The web application is used by road managers to draw the road on Google Maps using polyline feature. With this our goal is to systematize the handling of damaged roads information, leading to faster service times and hopefully help reduce the level of traffic accidents in Indonesia.
\end{abstract}

Keywords: Complaint, Damaged road, Geographic Information System, Google Maps, Road digitization.

\section{Introduction}

Indonesia is an archipelagic country consisting of thousands of islands. An archipelagic country must have a good road infrastructure to facilitate the distribution of goods and services so that development occurs evenly in each region. The function of road infrastructure is not only to connect one area to another but also in the distribution of information, distribution of production facilities, distribution of products or production, and smooth transportation and communication. Road infrastructure is a locomotive to drive economic development in urban areas and rural areas.

Several factors can cause the damaged road infrastructure; waterlogging, temperature change, weather, air temperature, pavement construction materials, unstable subgrade conditions, the bad compaction process, and the overload of vehicles. The negative impact of 
damaged road infrastructures is the obstruction of goods and services distribution that can caused uneven economic growth, traffic accidents and congestion, etc.

Indonesia as an archipelago of its size, contains diverse terrain conditions in each province that needs to be assessed by construction managers. Maintenance of public routes are difficult due to the increasing number of roads spread across the area, and as a result may cause a lot of damaged transportation facilities in its distribution. Badan Pusat Statistik Indonesia shows that the rate of traffic accidents in Indonesia has increased by an average of $3.30 \%$ in $2014-2018$, recording a rise from 95.906 to 109.215 cases within the time frame. Several factors have contributed to this figure, one of which is the damaged roads that becomes a constant source of traffic accidents in each year [1].

Damaged road occurs due to road conditions that escape the attention of road managers. The role of community in the problem of damaged road will greatly assist road managers. The community can make complaints about damaged roads by reporting the road conditions encountered to road managers. However, people in general still make complaints about damaged roads manually, which causes people to know who the road manager of the road they want to report. Complaints about damaged roads manually cause the complaint's wrong purpose, so that takes a long time to be processed and even become unprocessed.

Research on mapping and complaints of damaged roads has been done before namely Mapping of Damaged Roads and Bridges in Kalisat District, Jember Regency using a Geographic Information System. This research development provides suggestions that the system created can assist in processing damaged road complaints, especially in the point of damage location [2]. Similar research on mapping the level of road damage has been done before using a web-based geographic information system that provides suggestions for further research that the system can also be developed on the android platform [3]. Similar research on mapping the rural road has been done before using a web-based geographic information system. This research uses map box API as the system's main map and uses the polyline feature to determine road managers [4].

This research aims to do mapping and make complaints on damaged roads using a geographic information system based on an android application and a website application using the google maps API. Road-mapping will be carried out by the road manager with the polyline feature from the google maps API so that complaints are directly directed to the authorized road manager. This research is expected to help the community make complaints about damaged roads effectively, assist road managers in carrying out road maintenance, and reduce the rate of traffic accidents.

\section{Research Method}

This research was built using the google maps API to do road mapping and complain of damaged roads. Mapping is done using the polyline feature of the Google Maps API. Methodologies used in Geographic Information System for Mapping and Complaint of Damaged Roads are as follows.

a. Requirements Identification Identifying requirements through the analysis of previous case studies, stakeholders, problem solving, basic research and evidence collection to support the proposal;

b. Literature Study

Literature Study is carried out by gathering various literature that are related to the topic of interest, referencing to similar case studies and researches that have been done before, approaches to design state-of-the-art systems and supporting theories in research.

c. System Development

Planning and designing the system as a whole; which include the identification of use cases, designing the system flow, flowchart and database design to facilitate the implementation process.

d. System Implementation Implementation of designs in previous stage, involving the output of code for several small programs called "units" where each must be tested for the functionality before being integrated into a single system.

e. $\quad$ System Integration \& Testing 
Integration of all programmed units and thorough system testing, which also includes fixing bugs or errors that are obtained during the testing stage.

\subsection{System Overview}

Geographic Information System for Mapping and Complaint of Damaged Roads consists of two platforms; a mobile app created for Users for reporting and viewing information, and a web dashboard for Administrators and Road Managers to organize complaints. The system utilizes several libraries from Google Maps API to enable mapping, complaint tracking and road management. The following diagram shows a general overview of the system.

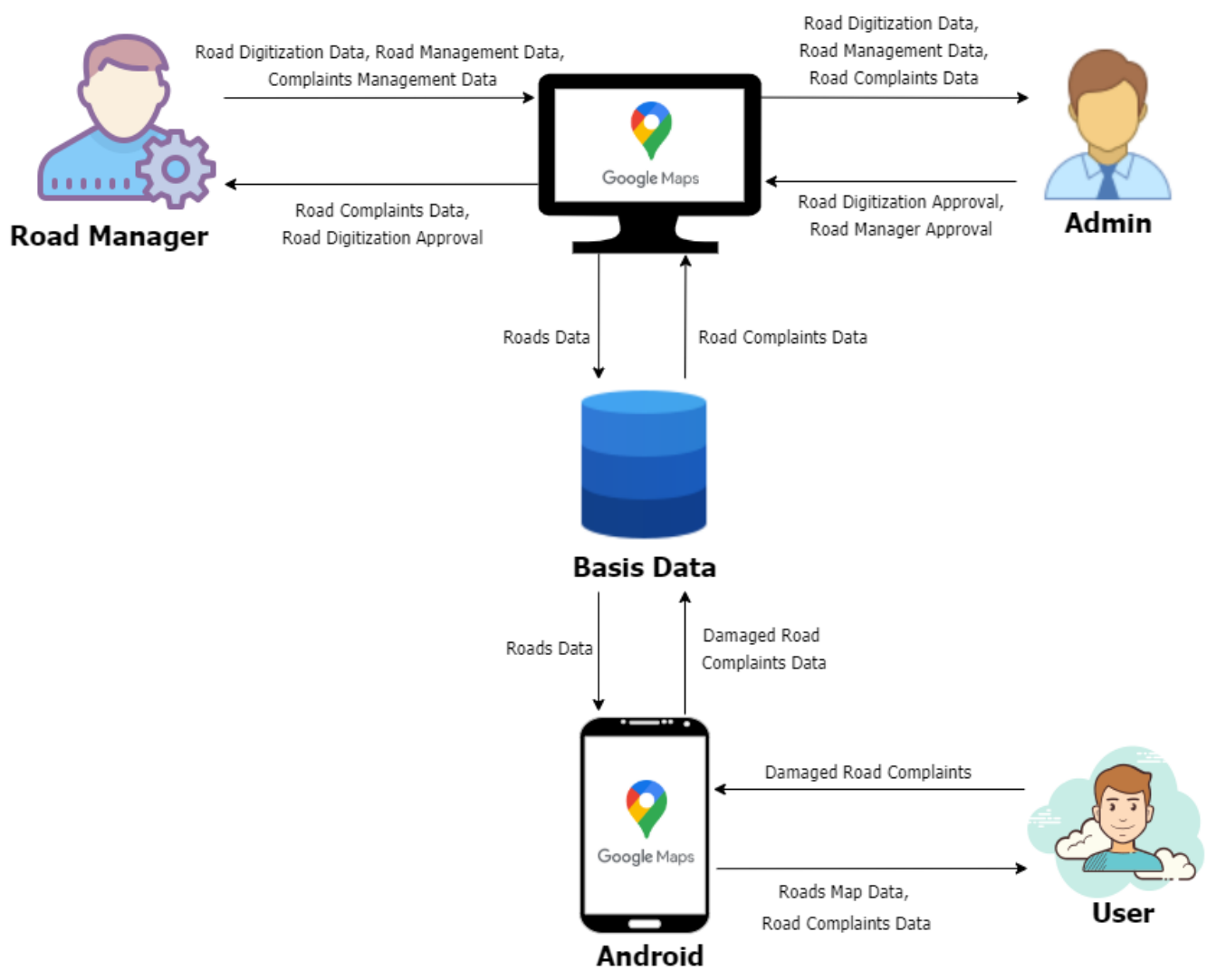

Figure 1. System Overview

As illustrated above, the Geographic Information System for Mapping and Complaint of Damaged Roads consists of three different actors; Road Manager, Admin, and User. User can submit their reports and complaints of damaged roads to the Road Manager, who will then digitize all reports on the website. Digitizing the roads is also indicate that the operating Road Manager is in charge of that project. The Administrator can then review all of the users' road complaints in the area, and approve the digitized map from the Road Manager.

\section{Literature Study}

Collection of theories obtained from books, research journals and articles, internet sources and other literature to support the basis of creating an application.

\subsection{Geographic Information System}

Geographic Information System (GIS) is a system designed to capture, store, manipulate, analyze, organize, and display all aspects of geographic data. GIS is composed of the concept of several layers (layers) and relations. The geographic information system improves the system's ability to analyze spatial information for planning and decision making. The system may be identified as a GIS if it contains features that can process geographic data such as the longitude, latitude, coordinates, and other related information [5]. 


\subsection{Android}

Android is a mobile information system created by Android Inc which was purchased by Google in 2005. Android is designed as a versatile operating system that can be optimized for low-powered devices that are battery-run and became widely supported by daily appliances and electronics such as GPS receivers, cameras, light sensors, wifi, and touch screens [6]. Developers can easily create applications with a variety of virtual devices that Android has provided. Initially, Google Inc. buy Android Inc., the newcomer who makes software for mobile phones. The Open Handset Alliance was formed to develop android sustainably. Android version 3.0 and above are no longer handheld devices but use mobile devices in tablets with larger sizes, approximately twice the size of ordinary mobile devices [7] .

\subsection{Kotlin Programming Language}

Kotlin is a Java Virtual Machine (JVM) programming language developed by JetBrains. It is a pragmatic programming language for Android which fuses Object-Oriented (OO) with functional programming. Kotlin is also an interoperable programming language that allows it to to be incorporated in Java-based environments. Kotlin can be applied for desktop and web applications development and even for the backend processes [8].

\subsection{Laravel Framework}

Laravel is an open-source contemporary framework for web applications, widely used for desigining responsive websites. Laravel tries to make development more accessible by reducing common tasks used in most web projects, such as sessions, routing, caching, and authentication. The Laravel framework was founded by Taylor Otwell in 2011, for developing website applications based on the MVC architecture (Model View Controller). Laravel aims to make the development process enjoyable for developers without compromising the functionality of the application [9].

\subsection{MySQL}

MySQL is a RDBMS (Relational Database Management System) application, which is used to manage databases that apply relational principles to store its values. Each table of data are interconnected through the relation of primary keys, linking within tuple (records) and attributes (fields), in the commonly-known form of rows and columns [10].

\subsection{Roads}

The road is public transportation facility which is crucial to connect logistics for human resources and supplies. The availability of good road infrastructure is vital to sustaining the ever-growing economy and a positive impact of decentralizing the urban population through the increased development of rural areas. Roads function as a bridge between numerous facilities in the form of arterial roads or streets, collector roads, local roads, and neighborhood roads [11].

\subsection{Google Maps API}

Google Maps is a mapping service developed by Google. Geographic system information can be developed with google maps to obtain location data. Google Maps provides an API (Application Programming Interface) that allows other developers to take advantage of Google Maps in their application development [12]. Google Maps API is a library created by Google for aplications that require access to the Maps features. Some of which include polyline, polygon, marker, and other related types. Google Maps API is very flexible as it can be implemented to various platforms [13].

\section{Result and Discussion}

The result explains the implementation of the Geographic Information System for Mapping and Complaint of Damaged Roads. The Add Road Digitization Page can be seen in Figure 2. 


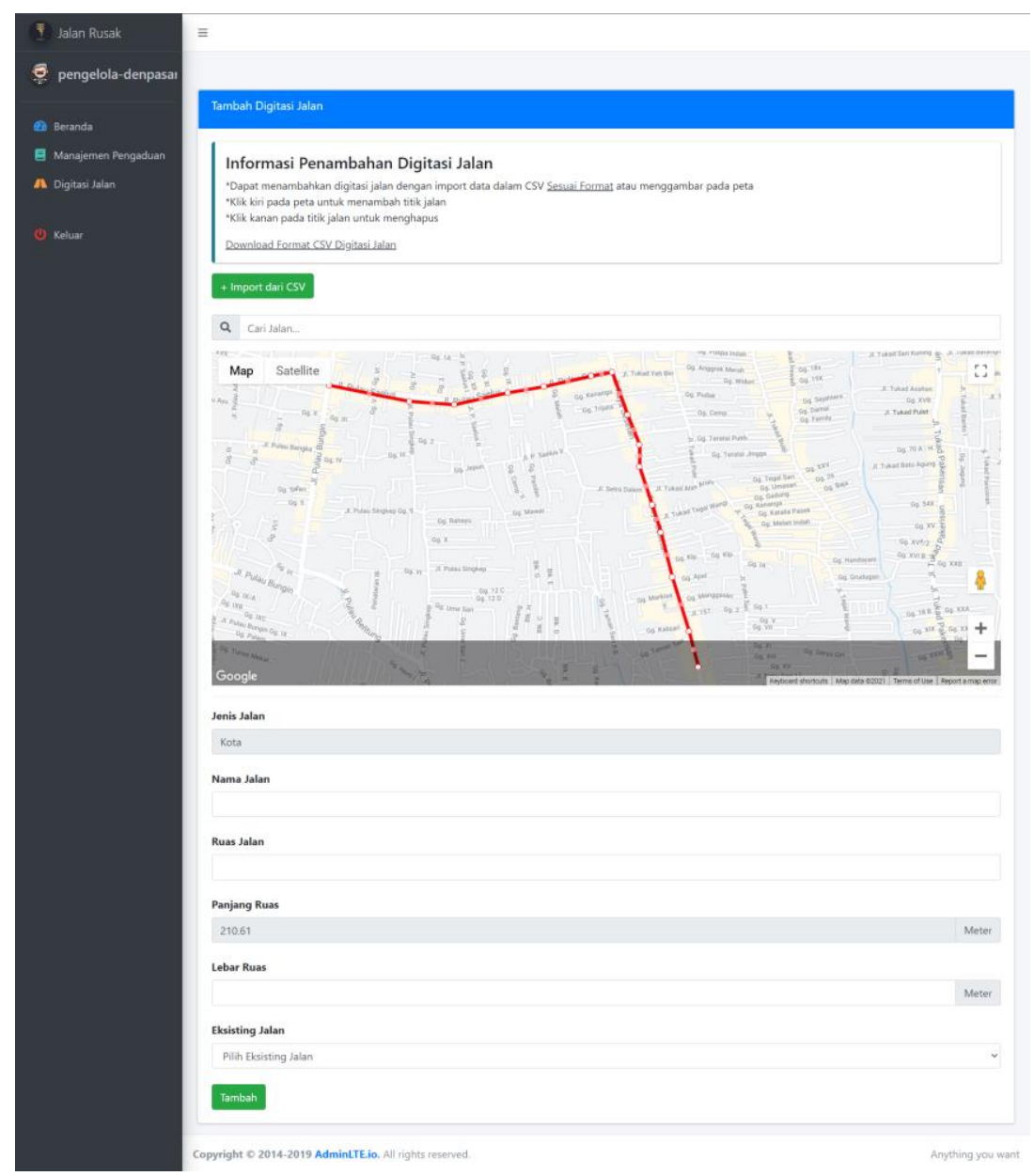

Figure 2 Add Road Digitization Page

Road Managers can add managed roads by digitizing roads on maps using two methods: drawing on the map and importing data based on a provided csv template available on the website. The system automatically digitizes the road when the user imports a CSV file. The system automatically calculates the road's length based on the inputs provided by the Road Manager. The system validates automatically if the Road Manager has digitized roads outside of their managed area. The Road Complaint Management page can be seen in Figure 3.
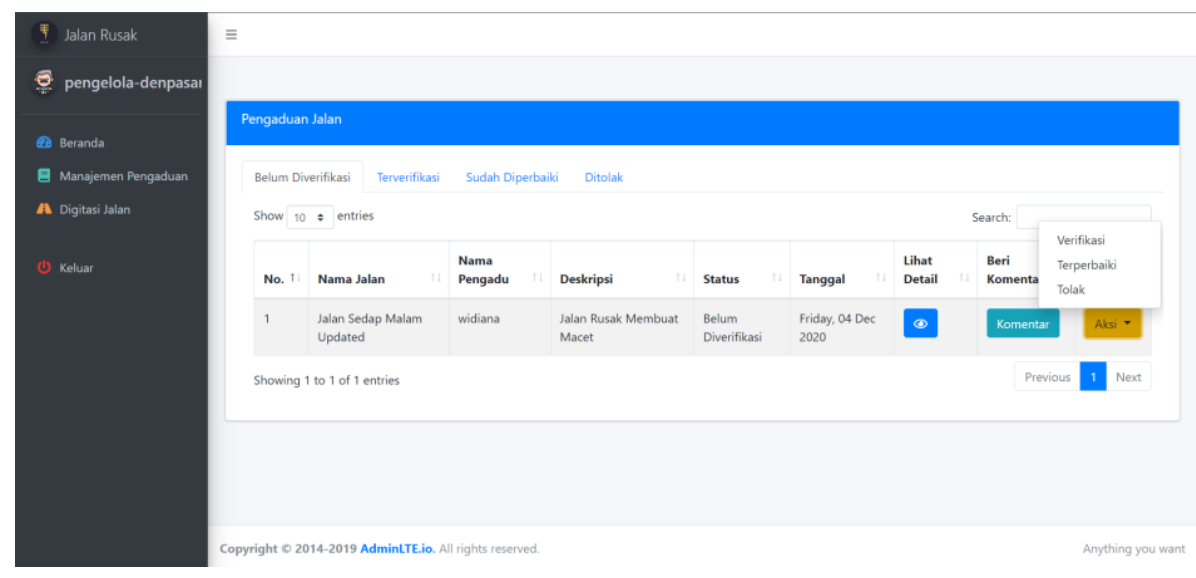

Figure 3 Road Complaint Management page 
The Road Manager can manage all road complaints. Any complaints originating from the Manager's area will be displayed in the table, where all information such as the road's name, complainant's name, complaint description, resolve status, and date of issue are shown. The managers can review and change the resolved status as the project goes on. The road manager navigates to the road complaint management detail page by pressing the lihat detail button. The Road Complaint Management Detail page is shown on Figure 4.

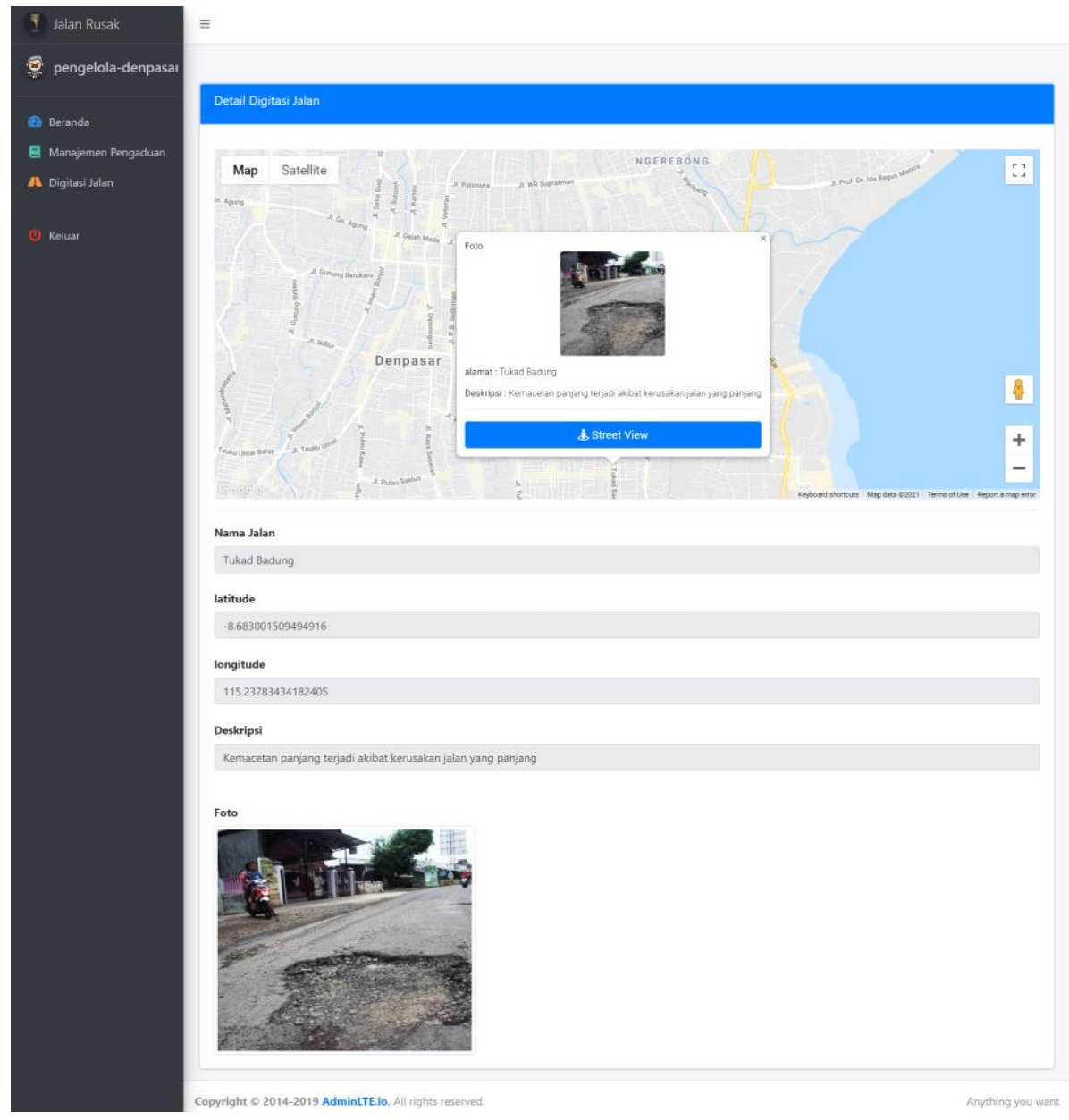

Figure 4 Road Complaint Management Detail Page

The Road Complaint Management page containts road complaint information. The road manager can see the complaint point, street view of the road complaint point, street name, latitude, longitude, description, and photos of road complaints. The Administrator's Road Digitization Validation page is shown on Figure 5. 


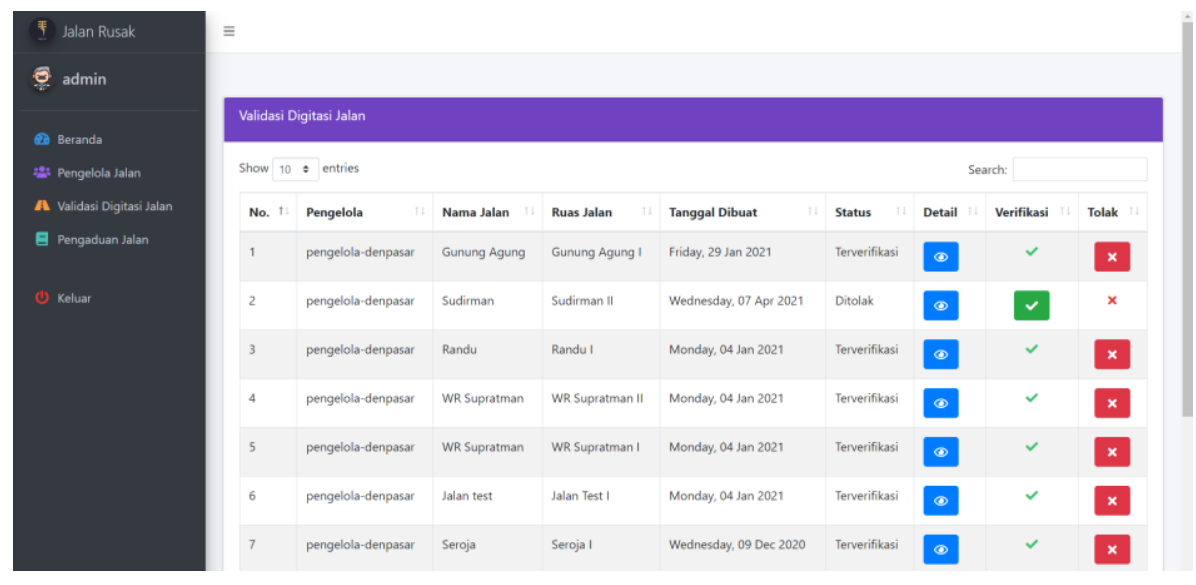

Figure 5 Road Digitization Validation Page

The Road Digitization Validation page contains all road digitization inputted by the Road Manager into the system. The Administrator is able to see the manager name, street name, date created, status, and other details. Approval buttons are available to change the road digitization status. The Administrator's Road Complaints page can be seen in Figure 6 .

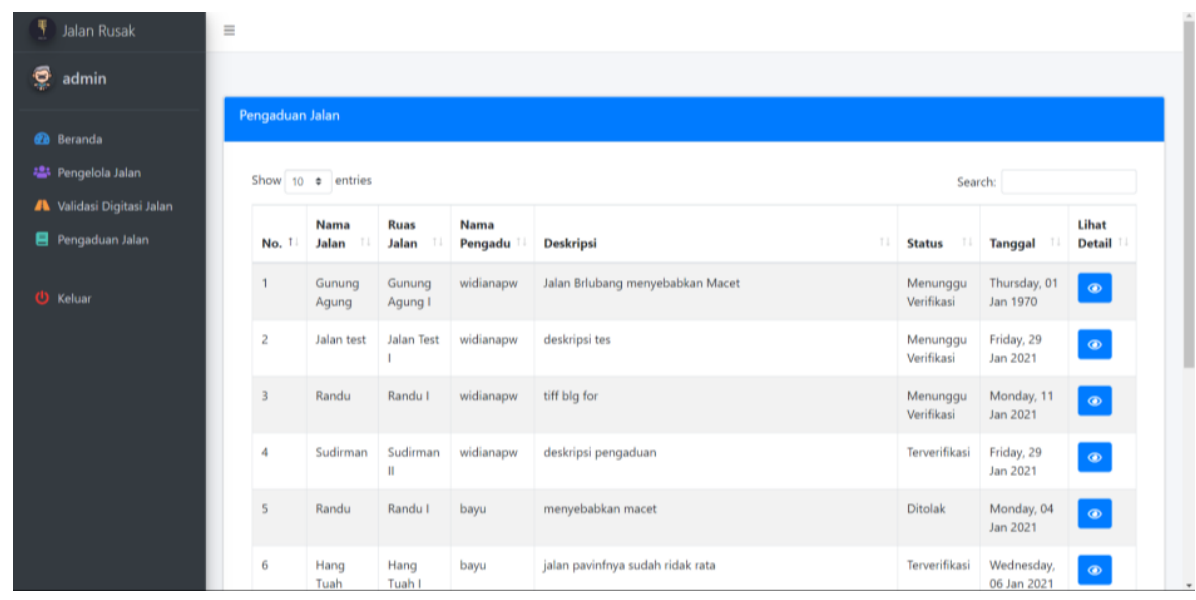

Figure 6 Administrator's Road Complaints Page

The Administrator's Road Complaints page can be accessed by the Administrator, containing information about road complaints submitted by users. The administrator is able to view the street name, complainant's name, complaint description, complaint status, and date of road complaint. The User's Home page can be seen in Figure 7. 


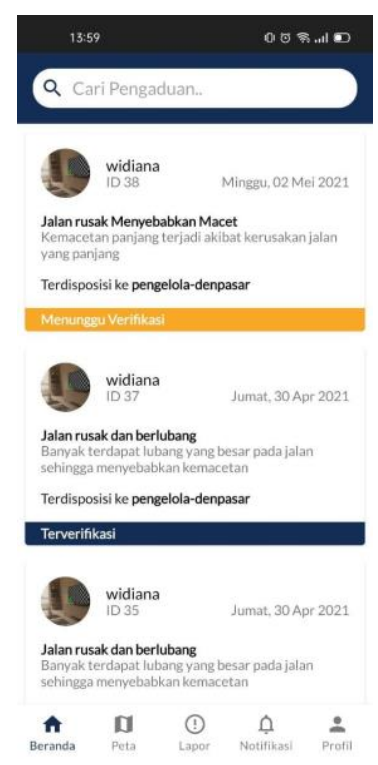

Figure 7 User's Home Page

The user can view all submitted complaints from themselves and other users through the Home page. The user can also use the search bar and look for specific road complaints by typing keywords. The user is directed to the complaint's details page when clicking on an item. The Add Complaint page is shown on Figure 8.
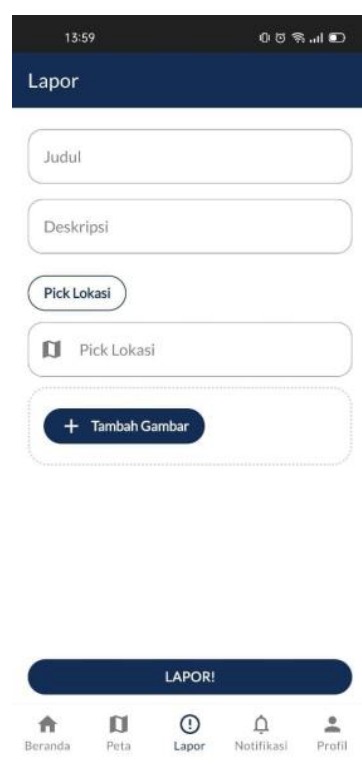

Figure 8 Add Complaint Page

The user can add new road complaints where each entry is submitted for the road manager's review. The user can write a complaint by filling in the title, description, address or location of damage, and picture attachments. The user can pinpoint their location by tapping on the Pick Location button, which shows an integrated Google Maps. The Road Map page on this interface is shown on Figure 9. 


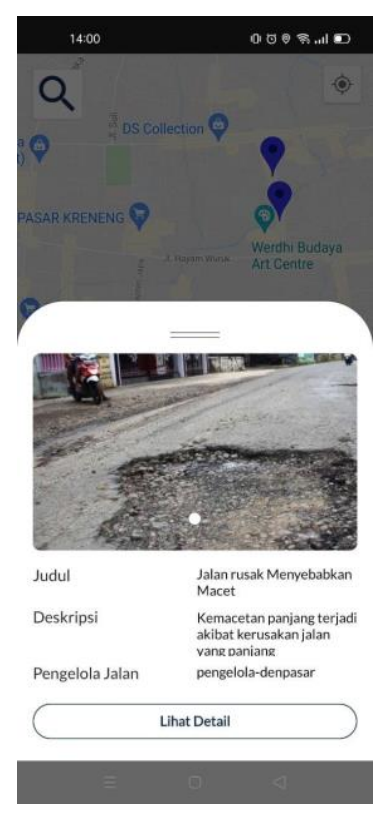

Figure 9 Road Complaint Map Page

The user can view pins of verified complaints. Information of the area featuring its photos, road's name, description, and the name of Road Manager in charge of the location by pressing the markers on the map. The user navigates to the user's road complaint detail page by pressing the lihat detail button.The User's Road Complaint Detail page is shown on Figure 10.
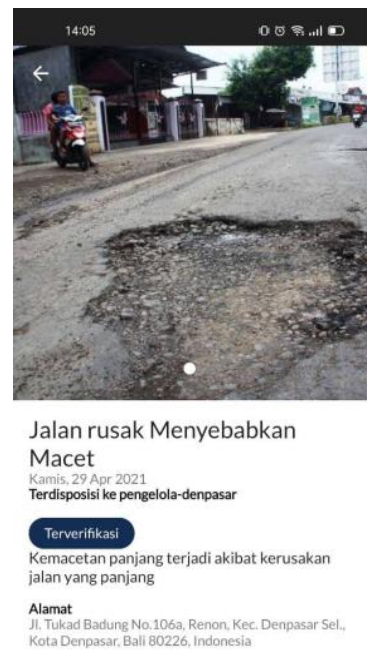

Figure 10 User's Road Complaint Detail Page

The User's Road Complaint Management page containts road complaint information. Users can see complaint detail data, such as photo, title, date, road manager, description, and address of the complaint on the user complaint detail page. The User's Notification Page is shown on Figure 11. 


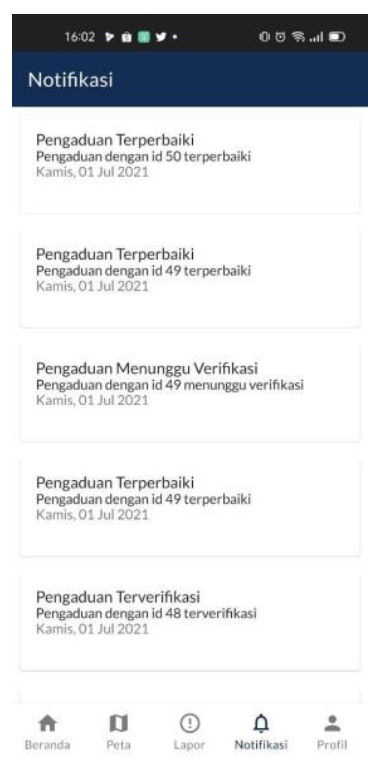

Figure 11 User's Notification Page

The user will get a notification if there are status changes to the user's complaint. The user can view the notification history of the complaint status changes on the user's notification page. The User's Profile Page is shown on Figure 12.

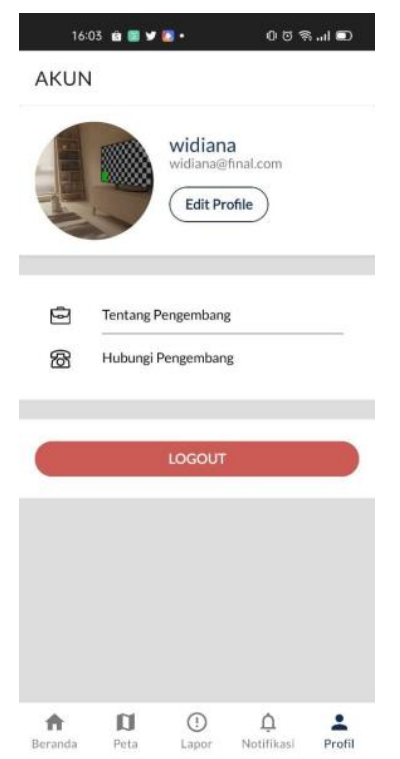

Figure 12 User's Profile Page

The user can view the user's data, change the user's data, log out, and view developer contacts on the user profile page. The user's data was obtained when the user does register on the application.

\section{Conclusion}

The Geographic Information System for Mapping and Complaint of Damaged Roads provides better efficiency for managing complaints, as it streamlines the formal process between Users and Road Managers. The road managers are able to do road digitizing by drawing points on the map or importing CSV data to the system. Administrators are able to 
review and validate all road complaints mapping done by the Road Manager, based on the Users' entries that have been verified. Users, too, can be informed by viewing all damaged road complaints that have previously been made or add a new complaint more effectively.

\section{References}

[1] Badan Pusat Statistik, "Statistik Transportasi Darat 2018," 2018.

[2] S. Ardi et al., "Pemetaan jaringan jalan dan jembatan rusak menggunakan sistem informasi geografis di kecamatan kalisat kabupaten jember," Inf. Technol. J., vol. 3, no. 1, pp. 19-28, 2017.

[3] M. S. Lauryn and M. Ibrohim, "Sistem Informasi Geografis Tingkat Kerusakan Ruas Jalan Berbasis Web," JSil (Jurnal Sist. Informasi), vol. 6, no. 1, p. 20, 2019.

[4] L. Gede, S. Handayani, I. N. Piarsa, and K. S. Wibawa, "Sistem Informasi Geografis Pemetaan Jalan Desa Berbasis Web," Lontar Komput., vol. 6, no. 2, pp. 128-137, 2015.

[5] S. Rahayu, I. N. Piarsa, and P. W. Buana, "Sistem Informasi Geografis Pemetaan Daerah Aliran Sungai Berbasis Web," Lontar Komput. J. IIm. Teknol. Inf., vol. 7, no. 2, p. 71, 2016.

[6] H. Kusniyati and N. S. Pangondian Sitanggang, "Aplikasi Edukasi Budaya Toba Samosir Berbasis Android," J. Tek. Inform., vol. 9, no. 1, pp. 9-18, 2016.

[7] I. W. N. Artha and I. N. Piarsa, "Sistem Informasi Geografis Pura Di Pulau Bali Pada Platform J2me," Merpati, vol. 1, no. 2, pp. 1-9, 2016.

[8] S. Bose, "a Comparative Study: Java Vs Kotlin Programming in Android Application Development," Int. J. Adv. Res. Comput. Sci., vol. 9, no. 3, pp. 41-45, 2018.

[9] V. V Parkar, P. P. Shinde, S. C. Gadade, and P. M. Shinde, "Utilization of Laravel Framework for Development of Web Based Recruitment Tool," IOSR J. Comput. Eng., pp. 36-41, 2016.

[10] K. I. Satoto, R. R. Isnanto, R. Kridalukmana, and K. T. Martono, "Optimizing MySQL database system on information systems research, publications and community service," Proc. - 2016 3rd Int. Conf. Inf. Technol. Comput. Electr. Eng. ICITACEE 2016, pp. 1-5, 2017.

[11] F. Yudaningrum and I. Ikhwanudin, "IDENTIFIKASI JENIS KERUSAKAN JALAN (Studi Kasus Ruas Jalan Kedungmundu-Meteseh)," Teknika, vol. 12, no. 2, pp. 16-23, 2017.

[12] D. Ayu, I. Cahya, I. N. Piarsa, and I. M. Sukarsa, "GIS Pemetaan Gallery Kerajinan Seni Di Bali Berbasis Web Mobile," Merpati, vol. 2, no. 3, pp. 400-408, 2016.

[13] M. Sholeh, N. Widyastuti, and M. Pratama, "Google Map for Implementation of Geographic Information System Development Search Location SMEs," Int. J. Eng. Res. Technol., vol. 6, no. 2, pp. 501-504, 2017. 